\title{
THE UNBEARABLE LIGHTNESS OF DIGITAL ACTIVISM: THE EFFECT OF GENDER ON SOCIAL ACTIVIST PARTICIPATION LEVEL OF UNIVERSITY STUDENTS
}

\author{
DIJITAL AKTIVIZMIN DAYANILMAZ HAFIFLIĞI: CINSIYETIN ÜNIVERSITE \\ ÖĞRENCILERININ SOSYAL AKTIVIST KATILIM DÜZEYINE ETKISI
}

\author{
Elif ŞEŞEN $^{1}$ - Perihan ŞIKER ${ }^{2}$
}

\begin{abstract}
The study aims to understand the participation status of the university students in the protest activities defined as digital or social activism, which are organized commonly through social media in the example of Niğde Ömer Halisdemir University. The survey to get data regarding the participation situtation of the students to various protest activities that starts online and are delivered offline and the effect of gender on this participation was applied to 320 individuals. The study results deduced out of testing three hypothesis in total showed that online activities have small effects on reality. The reactions are limited to subscribing or likes, and $80 \%$ of the students, that is four out of five students, do not participate in these physical offline activities. Also the percentages of respondents who answered negatively in participation to activist actions about $54 \%$ in women and $58 \%$ in men. It might be said that there is no a significant difference between genders.
\end{abstract}

Keywords: Digital activism, online/offline activities, social media

$\ddot{\mathbf{O z}}$

Bu çalışma, Niğde Ömer Halisdemir Üniversitesi örneğinde üniversite öğrencilerinin dijital ya da online aktivizm olarak tanımlanan ve yoğunlukla sosyal medya üzerinden gerçekleştirilen protesto eylemlerine katılım durumlarını anlamaya yöneliktir. Öğrencilere çevrimiçinden çevrimdışına yani online'dan dış çevre'ye doğru giden bir yelpazede çeşitli protesto aktivitelerine katılım durumları ile cinsiyetin bu katılıma etkisine dair veri elde etmek için 320 kişiye anket uygulanmıştır. Toplam üç hipotezin test edildiği çalışma sonuçları sanal eylemlerin gerçek yaşama etkilerinin sınırlı olduğunu ve ayrıca cinsiyetler arasında bir farklılık olmadığını göstermiştir. Öğrencilerin tepkileri bir gruba üye olmak ya da bir sayfayı beğenmekle sınırlı kalmakta öğrencilerin neredeyse \%80'i yani her beş öğrencinin dördü fiziksel bir çaba gerektiren diş çevredeki aktivitelere katılmamaktadır. Aktivist eylemlere katılıma olumsuz cevap verenlerin oranı kadınlarda yaklaşık \%54 ve erkeklerde \%58 olup cinsiyetler arasında bir fark olmadığı söylenebilir.

Anahtar Kelimeler: Dijital aktivizm, çevrimiçi/çevrimdışı eylem, sosyal medya

\footnotetext{
${ }^{1}$ Dr.Öğr.Üyesi, Niğde Ömer Halisdemir Üniversitesi, elifsesen@ gmail.com, ORCID:0000-0002-8513-9647

${ }^{2}$ Niğde Ömer Halisdemir Üniversitesi, gungorperihan@ hotmail.com, ORCID:0000-0002-0787-8516
}

Makale Türü: Araştırma Makalesi - Geliş Tarihi:12/03 /2018 - Kabul Tarihi:12/12/2018 


\section{Introduction}

Participation in social and political protest activities was mainly biased by age, gender, and education (Gallego, 2007). The youth of the university, who is the educated group of the society, comes to the fore as the ones who have a critical approach and therefore, as the inclined to social actions, who first catches the waves of social change and who are not yet fully involved in the current system. This state of agency, which is sometimes connected to natural personality characteristics, such as being curious, inconstant, innovative, rebellious, revolutionist and which is sometimes seen as a result of the education they receive or the responsibility towards the society, has the potential to make students more responsive to social problems and to make these problems more exciting to be mentioned. University students tend to be more socially and politically active than other young people (Calenda and Meijer, 2009). However, developments such as internet technologies and globalization deeply affect the character and participation potential of youth. Numerous studies about the young people suggest that they are less engaged in politics nowadays. They have very low levels of political interest and knowledge, they do not trust politicians, and they do not believe they have the power to change anything (Dalton \& Wattenberg, 2000; Putnam, 2000). Jean Twenge (2009) speaks of a similar trend in the United States in her book, Generation Me, in which she interprets the results of 12 studies based on information about 1.3 million students and states that from the year 1966 to 2000, the proportion of students who think that dealing with political events is an important goal of life declined from $60 \%$ to $10 \% .1 \% 6$ ung people with limited socialization spend most of their time in front of TV in their homes, while they satisfy their social needs with social networks on the internet. Social networks convey the messages quickly and effectively which raise awareness by enabling interaction between societies and which reflects the call for 'another world is possible' on both global and local line (Karagöz, 2013). Is the Internet and its fruits like Facebook, Twitter, and etc. a new and free platform for political participation of youth really? Answer of this question is "certanly yes" for some authors but others are not sure about democratic or political potential of the Internet. The Internet and social media represents both an opportunity and a challenge. According to Kellner (1999: 109), who accepts the Internet as a mean for democratic participation, said that the Internet can ensure “...ordinary citizens and activists to become political actors and communicators, to provide information, and to participate in debates". For Boulianne (2015: 525) "social media creates social networks ties for groups, organizations and activists". The statement that the Internet and the social media creates new opportunities is based on the idea that the interactive technologies ensure political freedom. However, this approach is criticized in a way that it neglects the digital gap which implicates the limitations in the means of access, that are dependent on class, regional, sexual, racial, etc. variables.

The people who are more skeptical of the internet pave the way for political participation with the new form of opposing of the internet and social media, as well as they argue that this kind of organization and agency is rarely moved into everyday life. Some also says that these protest activities named digital or online activism, which are made on the Internet or social media, incite passive activism, and that they cause people to relieve by acting ineffectively as if they participate in some kind of activity. The passivative effect of mass media tools is not a recent subject. Lazarsfeld and Merton (1948) wrote three main functions of the mass media as the status conferral function, the enforcement of social norms and the narcotising dysfunction. In third effect, the media prevents the spectator to react and interfere with social problems, narcotize the spectator and make him/her unresponsive. The spectator spends their time on reading, listening and receiving information, rather than participating in the organizational activity. This causes the spectator to reject that he/she is not a participant in the activity. Through media, he/she receives information, is concerned, and 
knows what have happened or will happen. However, he/she stays passive, rather than acting. Now, even if he/she is not limited by just receiving information, it seems hard to not be possessed with the unbearable lightness of online action for the postmodern human as a world citizen included in a social game by a click. Milan Kundera writes "So, is the heaviness hateful, and is lightness blinding? Which one to choose, then? Heaviness or lightness?" in his famous novel The Unbearable Lightness of Being. Is to act a heavy burden, or is to believe just by a click to lighten? Does the activism on Facebook or Twitter presents this lightness to the postmodern individual? Zhang, Johnson and Seltzer (2009) found that social media use was significantly related to increased civic participation especially for young people but findings of Baumgartner and Morris (2010) study are contrary. According to the researchers potentially, they do nothing more than mobilize internet-related activism, but not other types of participation. In the light of this, it might be said that this subject needs further research.

Another important factor affecting participation is gender. Several studies have been conducted on the nature and causes of gender differences in participation in social actions. Women's social and political activity level has recently increased such as in attending protest, working in campaigns (Rosenstone and Hansen 1993; Verba, Burns and Schlozman 1997) but they still have been less interested in political issues and less frequently participate to civic and political discussions and collective action than men (Norris 2002; Schlozman, Burns and Verba 1999; Verba, Burns and Schlozman 1997; Coffé, and Bozendahl, 2010). The effect of gender on participation is also observed among university students whose ages and educational levels are similar.

The present study intends to deepen our understanding of social media use and online activity affects offline participation. The main questions of the study are whether online activism remains limited its medium and whether gender is an effective factor for the participation. Because there is uncertainty in the literature regarding whether gender affects participation.

\section{Effects of the Internet on Participation}

Fenton and Barassi (2011) argue that new forms of socialization emerging with new communication technologies bring claims such as the facilitation of the transformation of the relationship between the citizen and the media as well as the facilitation of new forms of political and operational participation. Social media networks are at the heart of these new forms of socialization. Networks defined as social media have facilitated organizing with dialogue and sharing and have incited a new kind of activism, named "the digital activism". The term is used to describe any activity carried out in the digital environment. In fact, it seems difficult to talk about a type of activism that does not use the Internet anymore (Joyce, 2010: 2). Digital activism is now being implemented as a practice of communication and organization for social, reactive or supportive activities.

Graeff (2016: 95) accepts that new forms of digital activism have some problems but "if one thing defines this era of youth digital activism, it is the ability to make and widely share media" and social network sites like Facebook and Twitter are so important. The use of online social networks should be consired as collective action since social interactions and conntection is the objective on this platforms (Chi, Cheung \& Lee, 2008).

Recent studies show the importance of differentiating between two types of participation: offline and online. Online participation includes online activities devoted to influence government action with participation in public matters (Lutz, Hoffmann \& Meckel 2014). Gibson and Cantijoch (2013: 707) classified modes of participation as voting, campaing activities, protest activities, contacting, communal activities and comsumerism 
activities and modes of passive participation as news attention and discussion. There are similarities and differences between offline and online activities of these two modes. It might be said that donate, boycotting, signing a petition, sending messages, reading news are similar types of activities but they are practised virtualy not physically or in other words online not offline.

What counts as an non-institutional or expressive form of political engagement continues to be debated, but commonly cited examples include protests, petitions, boycotts and, more recently, online modes of engagement such as social media campaigns (Campbell 2009; Zukin, Keeter and Andolina 2006). Gibson and Cantijoch (2013) find that online expressive political activities are empirically distinct from offline forms of political participation. Oser, Hooge and Marien (2013) suggested that online activism is a distinctive type of political participation. Cantijoch (2012) found that Internet use has not an effect on all types of participation but has an impact on political interest. There are several studies found that online political interest and expression are associated with offline political engagement (Theocharis and Quintelier 2014; Yamamoto, Kushin and Dalisay 2013). But the results of the study of Metzger, Erete, Barton and Lewis (2015) indicate that, rather than substituting for offline engaged behaviors and providing a virtual outlet that replaces live action, online engagement activities at the very least correlate with offline engagement.

Some research report positive relationships between Internet use and different forms of civic and political participation (Bakker and de Vreese 2011; Mossberget8 Tolbert, \& McNeal, 2008; Quintelier and Vissers, 2008; Valenzuela, Park, \& Kee, 2009) but most of these studies have demonstrated similar participatory inequalities such as gender differences, as those already in place offline (Schlozman, Verba and Brady 2012; Xenos and Moy 2007). Non-political online activity can provide a pathway to participation in volunteering, protests and political voice (Kahne, Lee \& Feezell 2013; Xenos, Vromen and Loader 2014). According to the research results of Mossberger, Tolbert \& McNeal (2008) the Internet increases both offline and online participation but according to the research results of Boulianne (2009), Baumgartner and Morris (2010) effect of online activities is minimal on political participation. For some scholars online participation forms such as signing of online petitions, online donations are meaningful as offline participation forms (Cammaerts and van Audenhove 2005; Papachariss 2009) but for some scholars these forms of participation are so simple and inefficient (Barney 2010; Christensen 2011; Gladwell 2010; Morozov 2009). Online activities do not expand to offline activities (Gibson and Cantijoch, 2013; Hirzalla and Van Zoonen, 2010). For some scholars the Internet is a new medium to strengthen participation of the already active groups (Allbrecht 2006; di Gennaro and Dutton 2006; Willis and Tranter 2006). Boulianne (2015) in her meta-analysis which included 36 studies totally, suggests a positive relationship between social media use and participation in civic and political life but there is no significant data whether the effects are enough for transformation.

Three main effects of the Internet on participation and activism can be classiffied in these studies:

- The creative effect

- The impairing effect

- The strengthening effect

The Creative Effect: The "creative" effect advocating that the Internet is a primary way to achieve a participatory, transparent and direct democracy. The Internet has created a new media, a platform, a tool for social action. Enjolras, Steen-Johnsen and Wollebæk 
(2013:904) found that "participation in Facebook groups has a strong and independent effect on mobilization". Rheingold (1993) argues in The Virtual Community that the Internet has created new agoras as alternative meeting places for virtual groups, and that a sufficient number of people can discuss social issues by establishing relationships with human emotions in cyberspace. Kahn and Keller (2004:88) evaluated the Internet as a democratic and liberal way to be informed, to inform others, to establish new social and political relations by a citizen of this growing world. Those who point out the activist side of the Internet say that individuals can express themselves through the Internet technologies, spread information, and receive first in the virtual world and then in the physical world. Shirky (2011) points out that online activists believe in their power and their activities can help bring about political and social change.

The Impairing Effect: The "impairing" effect, which argues that the Internet, a thing that only a privileged section of the society can use, is inadequate for social opposition. With the opening of new forms of opposition and political participation, these forms of organization and activity are seldom carried to everyday life, and the effect is weak enough to be tried, even causing backlash sometimes, undermining the possibility of action. For example, around 20 thousand people clicked to participate in the protest at Zuccoti Park in New York on September 17, 2011, but only 300 people showed up even after spreading to other cities (Özdemir 2015). The fact that the response on the Internet can be demonstrated with just one 'click', a 'like' or a 'tweet' causes people to do that just to 'keepg up with the trend' so many internet activists do not even know what and why they support or oppose. While signing up for a campaign requires an effort, sometimes even a risk, a protest activity in the virtual environment is rather effortless and easy. According to Morozov (2011) people generally performed such activities for selfish and narcissistic purposes. Because those who share a social or political problem are often seeking social prestige rather than contributing to the solution of the problem. According to the results of the study conducted by Zhao, Grasmuck and Martin (2008) people join campaigns or click like button only for shaping their online identity and rarely act in a more physical way. Ward (2016: 169) points out "terms such as hashtag activism, clicktivism and slacktivism are often associated with online campaigns, and each term views online activism as narcissistic and lacking any substantial social impact". Halupka (2014:124) accepts clicktivism as "a unique form of online political participation". Rotman et al. (2011:3) define slacktivism as "low-risk, low-cost activity via social media, whose purpose is to raise awareness, produce change, or grant satisfaction to the person engaged in the activity". Slacktivism gives a kind of sense of moral justification without the need to actually engage (Lee and Hsieh 2013) or to move physically. As an online activism practice, 'slacktivism' and 'clicktivism' give the impression that they have done something to some subjects through online action by participating and they think that they act even during lunch time (Scholz, 2010: 27). Fenton and Barassi (2011) who draw attention to this risk, argue that online political participation like joining a Facebook group or retweeting a message might distort the meaning of collective action.

The Strengthening Effect: The "strengthening" effect which argues that the Internet can only affect those with current participation tendencies. It is not possible to say that online participation brings automatically offline activities but Calenda and Meijer (2009) claim that online participation is a strong trigger on offline participation. Social media groups and sharings support to real life public opinion. According to Dahlgren (2009) digitally networked communicative practices can strengthen civic identity which is the beginning stage of political participation. In fact there are some supportive results that the more politically active people the more generally use the Internet for online political debates and activities (Wellman, Hasse 
and Witte 2001). In other words the Internet has been used by people who are interested in politics in their daily lives.

\section{Youth Participation}

Today, the Internet, social media and mobile phones have been used considerably by young people and these tools have greatly enhanced the information and communication capacities of them, expanding their presence in public and political arenas (Wen, Xiaoming and George 2013). During this life-stage, young citizens have less of the resources (time, money or mental energy) that are believed to be prerequisites to political engagement (Verba, Schlozman and Brady 1995). However, as online participation requires fewer resources (financial or otherwise), it has been suggested that these online tools could help to compensate for the resource limitations that young adults face and provide a low-cost site for engagement (Keating and Melis 2017).

For a group of scholars such as Della Porta and Mosca (2005), di Maggio, Hargittai, Neuman and Robinson (2001), Norris (2002), young people are not willing to be involved in formal forms of political participation but rather participate in single issue movements and networks. There are studies (de Vreese 2005; Kahne and Middaugh 2012; Valenzuela, Park \& Kee 2009; Yang and DeHart 2016; Gil de Zúñiga, Jung and Valenzuela 2012) demonstrated that many Internet activities are positively related to different dimensions of civic and political participation. In the case of young people, the creative effect of the Internet is more prominent. Gil de Zúñiga, Molyneux and Zheng (2014: 621) argue that social media tools are promising platforms for young people's political activities and "young people and lessprivileged individuals tend to express their voice politically via social media". Boyd and Ellison (2008) explored that majority of university students use social media to connect with friends as well as strangers based on shared interest, political views or any other activities. Valenzuela, Park and Kee (2009) stated that there is a positive relationship between intensity of Facebook use and students' civic participation and political engagement. Also results of Dordevic and Zezelj (2016) study the Internet and new media has a positive impact on civic activism of young people. However some scholars could not find any positive influence of social media use on youth's political participation (Baumgartner and Morris 2010; Kushin and Yamamoto 2010; Quintelier and Vissers, 2008). Theocharis and Lowe (2016) found that Facebook use has negative effect on participation. Vissers and Stolle (2014) concluded that the mobilizational power of Facebook activity is mainly limited to online activities and stays medium-specific for young people. According to the findings of Visser and Stolle (2014) study, students who practice Facebook political or activist participation are not very different from non-participants.

The studies on the supportive and empowering impact of the Internet and social media states that the online participation of young people contributes to offline participation. Kahne and Middaugh (2012) note that young people who take advantage of new forms of engagement, such as social media, are actually more likely to vote than those who do not. Vitak et al. (2009) concluded that political activity on social media such as in Facebook and Twitter is significantly associated with political participation. In other words online activity stimulates offline activity among the young people. Carlisle and Patton (2013) concluded that online political interest is an important predictor of political participation among college students but according to Mihailidis' (2014) survey social media are rarely used for politics and sharing social problems. 


\section{Effects of the Gender on Participation}

Burns, Schlozman and Verba (2001) attribute the main reason on the gender difference in social action and political participation to the lack of demand for participation and emphasizes that the person should have some resources for this demand to occur. Brady, Verba and Schlozman (1995: 271) consider these resources as time, money and skill. From these sources, time stands for having free/suitable time for participating in activities and meetings; money stands for being able to financially support; and skill stands for the mental capacity needed to understand the social and political process. The status of these resources, which refer to personal characteristics, is closely linked to gender, education and income levels. Kalaycioğlu's (1983) study is about gender roles are the most important factors that affects political participation. However, it is seen that gender difference is mostly felt in nonvoting behaviors (Duran, 2005; Tatar, 2003).

There are a few studies regarding the relationship between gender and media use. Ono and Zavodny (2003) indicated gender differences in the Internet usage regarding the access, frequency and purpose. Although overall levels of media use are similar for young women and men (Roberts and Foehr, 2008) they differ in their online activities. Junco, Merson and Salter (2010) found that women spend more time on social networking sites than men. According Bimber (1999) the impact of media use on men and women's political engagement is likely to be different. Other studies resulted that men took greater interest in politics, finance, news, sports while women more frequently visited those websites that dealt with home, family and religion (Jackson, Ervin, Gardner \& Schmitt 2001; Wasserman and Richmond-Abbot 2005). Findings showed that gender differences in political participation have been persistent over time and across different countries (Delli Carpini and Keeter, 1996; Jung, Kim \& Gil de Zúniga 2011). Women are equally active in community activities, grassroots movements, and NGOs than men (Enns, Malinick \& Matthews 2008; Burns, Schlozman and Verba 2001) but the results of the survey conducted by Coffé and Bolzendahl (2010) from 18 countries show that women are less involved in activities such as boycotts and donations. Study of Wen, Xiaoming and George (2013) revealed persistent gender gaps in various modes of political participation among young people, for example female respondents were less likely engage in offline and online political activities such as submitting political videos online and attending public demonstrations. These findings are consistent with other research (e.g., Coffé and Bolzendahl 2011; Atkeson and Rapoport 2003).

\section{Method}

As a population, students are extremely receptive to new technologies that they use in different manners and for various purposes and also young people are heavy social media users today (Rideout, Foehr and Roberts 2010). Varied researches have been conducted worldwide on youth's internet usage and social media such as Bohl (2015); Hamid, Ishak, Ismail and Yazam (2013); Johnston, Chen and Hauman (2013); Junco, Heiberger and Loken (2011); Pilli (2015). It is not a coincidence that those studies have been conducted largely on young people. Because the young is the social group which mostly use the Internet and social media.

On researches (Koçer, 2012; Tektaş, 2014) conducted in our country, it was seen that most of the time spent on the internet by the majority of university students is spent on social networks. Therefore, research was conducted on university students. This study was conducted on students of Niğde Ömer Halisdemir University because of the ease of access of researchers. The population of the study is the student community consisting of 8,612 students who are undergraduates at Niğde Ömer Halisdemir University in the academic year of 2016-2017 in six different faculties, including Faculty of Economics and Administrative 
Sciences, Faculty of Arts and Sciences, Faculty of Communication, Faculty of Architecture, Faculty of Engineering and Faculty of Agricultural Sciences. While determining the sample, a heterogeneous sample was tried to be formed by considering the distribution of the number of students in faculties and the gender factor.

Existing literature reviewed for the study but any questionnaire was not applied literally. While questionnaire preparing, studies benefited from are Dordevic and Zezelj (2016), Keating and Melis (2017), Metzger, Erete, Barton and Lewis (2015) and Pritzker, Springer and McBride (2012) for the survey. The preliminary survey was made for the efficiency of the content and the sufficiency for the analysis on ten students and then questionnaire was applied to 320 students using convenience sampling willingly participated from different faculties. The participants' age range from 18 to 24 . The survey was carried out between the date of 13-17 March 2017. It took approximately 15 to 20 minutes to answer the questionnaire. The questionnaire consists of two parts. In the first part, there are questions about the demographics of the respondents, while in the second part, respondents were asked a series of questions about their use of social media and online/offline activities. We focused on activities that Yamamoto, Kushin and Dalisay (2013) and Dordevic and Zezelj (2016) have described as online political expression, such as liking or sharing political information and participating an e-petition or a boycott. In this part, the participants were asked whether they will participate in the activities on a scale going from online activities such as "signing online petition campaign, sharing a message on a particular subject on social pedia account, informing friends on campaigns" and to offline activities such as "signing the campaign regarding the subject with real identity information, participating in an event/protest, inviting friends to this event." Thus, it was tried to understand whether online participation enhances offline participation.

The main goal of this study is to examine if there is a relationship between Internet use and online and/or offline participation activities of university students. The following hypotheses were tested in the study seeking to reveal youth's views towards digital activism.

H1. There is a significant relationship between sharing social problems on social media profiles and supporting protest activities.

H2. There is a significant relationship between subjects' gender and the social problems they share on their profiles.

H3. There is a significant relationship between subjects' gender and participation activities.

This study has some limitations. Convenience sampling was used in the study. However, studies examining interactions with social media frequently use convenience samples, including university students (Glynn, Huge \& Hoffman 2012; Junco, Merson \& Salter 2010; Lee and Ma 2012; Skues, Williams \& Wise 2012; Zhao, Grasmuck and Martin 2008). But sample size was small and limited to university students of Nigde Omer Halisdemir University. Results from this group are not generalizable to all the Internet users and also all university students.

Future researchers might focus on groups other than university students. Future researches should be conducted across the other universities and also other social groups. Ideally, it would be good to attempt to replicate this study with different educational and age groups in order to get a comparative picture of gender equality or inequality in participation. 


\section{Results and Discussion}

SPSS 19 statistical package program was used to analyze the data within the scope of the research. In this context, reliability analysis was performed first and Cronbach's Alpha value was found as 0.784 as the result of analysis. Then the data obtained from the survey results were analyzed statistically.

In the analysis of the data obtained from the research, the frequency distributions were used in examining the answers of the students to all questions in the first stage. In the second stage, it was analyzed by chi-square test whether there was a significant difference between the gender of students and their perspectives on digital activist actions. The chi-square test is one of the most common tests among non-parametric tests. The Chi-Square Independence Test is used in order to determine whether the relationship between the two variables is statistically meaningful or not (Eymen, 2007: 142). For determining the relationship between sharing social problems and participation rates in activist actions of the youth, Pearson Correlation test was used.

According to the results, 169 (53\%) of 320 students who participated to the survey was female and $151(47 \%)$ was male. Also $53 \%$ of the participants were studied on social sciences and $47 \%$ were studied on physical sciences. The most used social media accounts of the participants are Facebook, Twitter and Instagram respectively. It is similar to the worldwide proportion.

\section{3}

Students who participated in the survey were first asked whether they were aware of social platforms (such as change.org) that collected signatures related to social issues/problems. When $57 \%$ of respondents said yes, $43 \%$ said no. The percentage of those participating in any virtual signing campaign related to social problems such as problems of the handicapped, discrimination, violence against women was $42 \%$. The percentage of respondents who liked or retweeted a text/photo/video about a social problem was $83 \%$, and the percentage of respondents who answered yes when they were asked whether they share such a problem on their profiles was $72 \%$.

The results show that four out of five students participate in at least one subject or problem online on social media platforms. This result is much higher than the results of the study of Şener, Emre and Aky1ld1z (2015), which 64\% of the respondents say that they do not share social or political issues in social media, and also Demir's (2016) study, which the rate of participation in a political activity organized through social networking sites is about $37 \%$. However when the students, who stated that they share about the situations disturbing society, were asked if they would give their name and address information to a campaign organized on the same subject, only $48 \%$ of them answered yes. $31 \%$ were answered yes when asked to participate in an offline activity on the same subject. While less than half of the students stated that they would participate in the same campaign by giving their personal information such as real name and address, only one third of the students say they will participate in the same offline activity. $52 \%$ of the students said that to share a subject controversial to the common interest of the community is dependent on the content of the subject. When the participants were asked what kinds of social problems they could share on the page, the findings in Graph 1 were reached. According to Graph 1, students share the most violence against women/children on their profiles, and social problems related to the environment is at the second place. In the third place, they prefer to share responses to terrorist attacks. 


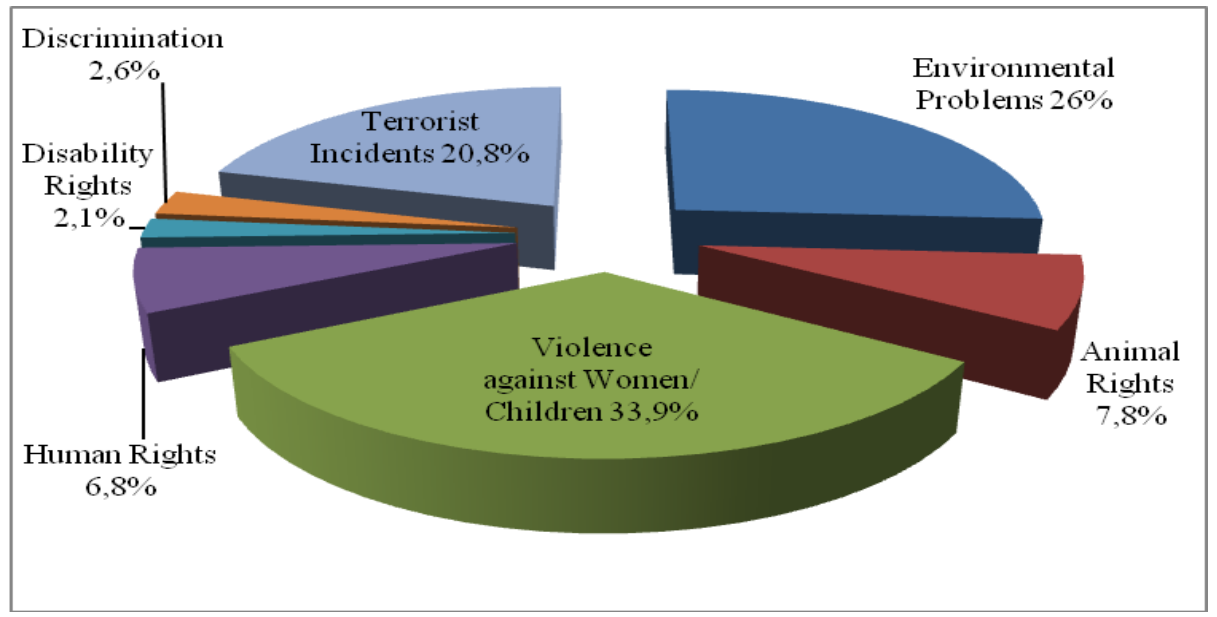

Graph 1: Distribution of Shared Social Problems

In the second step of the analysis the Chi square test was used to test hypotheses in the study. First of all, the relationship between social media sharings of students about social problems and their participation in activist actions were examined.

H1. There is a significant relationship between sharing social problems on social media profiles and supporting protest activities.

Table 1: Correlation Between Social Problems Sharing and Activist Action Participation

\begin{tabular}{llcc}
\hline & & $\begin{array}{c}\text { Sharing } \\
\text { social } \\
\text { problems }\end{array}$ & $\begin{array}{c}\text { Activist } \\
\text { action } \\
\text { participation }\end{array}$ \\
\hline Sharing social & Pearson & 1 & 0.071 \\
problems & Correlation & & 0.217 \\
& Sig. (2-tailed) & 320 & 320 \\
& $\mathrm{~N}$ & & \\
\hline \multirow{2}{*}{$\begin{array}{l}\text { Activist action } \\
\text { participation }\end{array}$} & Pearson & 0.071 & 1 \\
& Correlation & 0.217 & \\
& Sig. (2-tailed) & 320 & 320 \\
\hline
\end{tabular}

The "Pearson Test" was used to measure the relationship between sharing social problems on social media profiles and participation in activities related to problems. As seen in the table, the sig value was greater than 0.01 and the Pearson correlation coefficient was $r=$ 0.071. In other words, there is no significant relationship between sharing social problems on profiles and participating in an activity. Although young people share social problems on their profiles and demonstrate their sensitivity to these problems, they are reluctant to participate in protest activities related to these problems.

Findings of the research indicate that the youth's online activity does not bring the offline activity along and this result does not support Baumgartner and Morris (2010), Kushin and Yamamoto (2010), Quintelier and Vissers' study. Studies in our country also indicate a similar result. For example according to the study of Okur and Özkul (2015) for the most part (78.6\%) the students do not participate in activities to react or organize action. Research results of Şener, Emre and Akyıldiz (2015) also show that in the online political practices of the participants, passive actions (following, liking) outweighs the active actions (commenting, participation in petition, communication). 
H2. There is a significant relationship between subjects' gender and the social problems they share on their profiles.

Table 2: Chi-Square Test Results of Shared Topics

\begin{tabular}{lccc}
\hline \multirow{2}{*}{$\begin{array}{l}\text { Issues I can share } \\
\text { on my own profile }\end{array}$} & Female & Male & Total \\
\cline { 2 - 4 } Environmental problems & $39(23.4 \%)$ & $43(28.2 \%)$ & $82(26.0 \%)$ \\
\hline Animal rights & $17(10.3 \%)$ & $7(4.7 \%)$ & $24(7.8 \%)$ \\
\hline $\begin{array}{l}\text { Violence against } \\
\text { women/children }\end{array}$ & $74(43.9 \%)$ & $32(21.3 \%)$ & $106(33.9 \%)$ \\
\hline Human rights & $9(5.6 \%)$ & $12(8.2 \%)$ & $21(6.8 \%)$ \\
\hline Disability rights & $2(0.9 \%)$ & $5(3.5 \%)$ & $7(2.1 \%)$ \\
\hline Discrimination & $2(0.9 \%)$ & $7(4.7 \%)$ & $9(2.6 \%)$ \\
\hline Terrorist incidents & $26(15.0 \%)$ & $45(29.4 \%)$ & $71(20.8 \%)$ \\
\hline Total & $169(100 \%)$ & $151(100 \%)$ & $320(100 \%)$ \\
\hline
\end{tabular}

Chi-Square Tests

\begin{tabular}{lccc}
\hline & Value & df & $\begin{array}{c}\text { Asymp. Sig } \\
(2 \text {-sided })\end{array}$ \\
\hline Pearson Chi-Square & 18.403 & 6 & 0.005 \\
\hline N of Valid Cases & 320 & & \\
\hline
\end{tabular}

According to Table 2, the $\mathrm{p}$ value is less than 0.05 , revealing that there is a significant difference between women and men in terms of subject sharing. While women share reactions to violence against women/children, men share mostly reactions to terrorist incidents on their profiles. For both genders, shares on environmental problems came second in terms of importance. In women, terrorist incidents take the third place and animal rights take the fourth place. In men, violence against women / children takes the third place and human rights takes the fourth place. Bimber (1999), Roberts and Foehr's (2008) studies show that there is a difference in the contents of social media shares in young men and women. activities.

H3. There is a significant relationship between subjects' gender and participation

Table 3: Chi-Square Test Results

\begin{tabular}{|c|c|c|c|c|c|c|c|c|}
\hline & & \multicolumn{2}{|c|}{$\begin{array}{c}\text { Sharing Social } \\
\text { Problems Online }\end{array}$} & \multicolumn{2}{|c|}{$\begin{array}{l}\text { Participation to a } \\
\text { Petition }\end{array}$} & \multicolumn{2}{|c|}{$\begin{array}{l}\text { Participation to } \\
\text { Activist Actions }\end{array}$} & \multirow[b]{2}{*}{ Total } \\
\hline & & Yes & No & Yes & No & Yes & No & \\
\hline \multirow{3}{*}{$\begin{array}{l}\frac{\vec{v}}{\bar{v}} \\
\overrightarrow{0}\end{array}$} & Female & $\begin{array}{c}146 \\
(88.1 \%)\end{array}$ & $\begin{array}{c}23 \\
(11.9 \%)\end{array}$ & $\begin{array}{c}53 \\
(30.6 \%) \\
\end{array}$ & $\begin{array}{c}116 \\
(69.4 \%)\end{array}$ & $\begin{array}{c}78 \\
(46.3 \%) \\
\end{array}$ & $\begin{array}{c}91 \\
(53.8 \%) \\
\end{array}$ & $\begin{array}{c}169 \\
(100 \%)\end{array}$ \\
\hline & Male & $\begin{array}{c}116 \\
(78.2 \%)\end{array}$ & $\begin{array}{c}35 \\
(21.8 \%)\end{array}$ & $\begin{array}{c}49 \\
(31.7 \%)\end{array}$ & $\begin{array}{c}102 \\
(68.3 \%)\end{array}$ & $\begin{array}{c}64 \\
(42.3 \%)\end{array}$ & $\begin{array}{c}87 \\
(57.7 \%)\end{array}$ & $\begin{array}{c}151 \\
(100 \%)\end{array}$ \\
\hline & Total & $\begin{array}{c}262 \\
(83.4 \%)\end{array}$ & $\begin{array}{c}58 \\
(16.6 \%)\end{array}$ & $\begin{array}{c}102 \\
(31.1 \%)\end{array}$ & $\begin{array}{c}218 \\
(68.9 \%)\end{array}$ & $\begin{array}{c}154 \\
(48.3 \%)\end{array}$ & $\begin{array}{c}166 \\
(51.7 \%)\end{array}$ & $\begin{array}{c}320 \\
(100 \%)\end{array}$ \\
\hline
\end{tabular}




\begin{tabular}{|c|c|c|c|c|c|c|c|c|c|}
\hline & \multicolumn{9}{|c|}{$\begin{array}{c}\text { Chi-Square Tests } \\
\end{array}$} \\
\hline & \multicolumn{3}{|c|}{$\begin{array}{c}\text { Sharing Social } \\
\text { Problems Online }\end{array}$} & \multicolumn{3}{|c|}{$\begin{array}{c}\text { Participation to a } \\
\text { Petition }\end{array}$} & \multicolumn{3}{|c|}{$\begin{array}{l}\text { Participation to } \\
\text { Activist Actions }\end{array}$} \\
\hline & Value & df & $\begin{array}{c}\text { Asymp. } \\
\text { Sig. (2- } \\
\text { sided }\end{array}$ & Value & df & $\begin{array}{c}\text { Asymp. } \\
\text { Sig. (2- } \\
\text { sided }\end{array}$ & Value & df & $\begin{array}{c}\text { Asymp. } \\
\text { Sig. (2- } \\
\text { sided }\end{array}$ \\
\hline $\begin{array}{l}\text { Pearson Chi- } \\
\text { Square }\end{array}$ & 5.398 & 1 & 0.02 & $.040^{\mathrm{a}}$ & 1 & 0.842 & $3.982^{\mathrm{a}}$ & 1 & 0.046 \\
\hline $\begin{array}{l}\mathrm{N} \text { of Valid } \\
\text { Cases }\end{array}$ & 320 & & & 320 & & & 320 & & \\
\hline
\end{tabular}

According to Table 3, the percentage of women who share on their profiles social issues related to a social problem disturbing the society was $88 \%$ and the percentage of men was $78 \%$. According to the Chi-square test results, the $\mathrm{p}$ value is 0.02 and this value is less than 0.05 . So it might be said that women are more sensitive to sharing social problems than men. There is no difference between male and female participants in participating in a petition. About $70 \%$ of the both groups answered no. As the p-value is greater than 0.05 , there is no significant difference between male and female participation rates in signature campaigns. This result is similar to the study of Şener et al. (2015) which shows that there is no difference in terms of gender in sharing views on social or political probllebs on social media. According to Table 3, in both groups the majority answered no for participation to activist actions. While $46.3 \%$ of the women said that they would participate in an offline activity regarding social problems that disturbed the society, the percentage of men saying yes to the question was $42.3 \%$. The $\mathrm{p}$ value $(0.046)$ is smaller than 0.05 , so there is a significant relationship between subjects' gender and their participation in protest activities. While the findings show that there is no difference between men and women in terms of participation rate in petition, there is a difference between female students and male students about participation in activist actions even if it is a slight difference. This result is different from the studies that found that women's participation in offline activities is less than that of men such as Atkeson and Rapoport (2003), Coffé and Bolzendahl (2011) ile Wen, Xiaoming and George (2013).

\section{Conclusion}

Along with the improvements in communication technologies, the forms of communication have changed and the Internet has caused a transformative influence in people's life. As new communication technologies will reduce the cost of access to information, it will create new opportunities for participation and strengthen new groups. With the social media getting ahead traditional communication channels, a much faster flow of information has started among people. Thus, individuals have had the opportunity to express their thoughts and opinions without limitation of time and space through hashtags and to hear the voices of individuals with the same thoughts. However, the effects of virtual communities on real life are limited.

As the internet allows collective action, on the other hand, it actually emerges from the individuality of the persons one by one. Expressing individual opinions easily, by bringing together individuals with the same idea, not only provides collectiveness, but also facilitates the formation of atomized individuals who are expressing their opinions through their computer at home, independent of others.

For today's university youth growing with computer technologies, internet and social media are an ordinary part of their daily lives, and it is the basic and first way to share their 
individual thoughts with large groups. However, their activity in virtual courses is not carried to real life. The aim of this study is to understand what activities young people on the sample of the Niğde Ömer Halisdemir University students participate in on the online /offline activity scale, which goes from sharing social problems in social media profiles to participate in a protest event, and to understand whether the gender is effective on their participation.

When the findings of the study are examined, it is seen that young people support protest activities against social disturbances only through social media. Reactions of the students are generally limited to being members of a group, liking, commenting, that is, the virtual environment. Our results similar the studies of Baumgartner and Morris (2010), Boulianne (2009), Metzger, Erete, Barton and Lewis (2015), Okur and Özkul (2015). Although the popularity of new media opportunities affects the social network use of young people, it does not seen as sufficient to ensure political participation. In other words, the views that social media would be a driving force for the civic and political participation of young people (e.g. Dordevic and Zezelj 2016; Gil de Zúñiga, Molyneux \& Zheng 2014) have not been confirmed. Girls are more likely to share violence-related problems on their own profiles, while male students share reactions to terrorist incidents mostly. Although the majority of youth $(82 \%)$ are willing to share these issues on their profiles, the percentage of those who agree to participate in signature campaigns by giving their name and address information is $48 \%$. Only $31 \%$ of the young people surveyed stated that they can participate in protest activities related to social problems. Correlational analysis also reveals that there is no significant relationship between sharing a social problem on social media profile and participating in an activity related to the problem. That is, young people feel relieved with the emotion that they participate in campaigns to solve the social problems that they support by their keyboards, and they do not think physical participation is required for any protest activity about campaigns. Besides there is no significant difference between the ratio of male and female students who say they will participate in the signature campaign or demonstration.

When it comes to social action, it would not be wrong to say that the sensibility of university youth, who are the first category to come to mind, has decreased on social problems compared to the past. In 1968 which is the year of the students, it was written on a wall "Buildings do not go out on the streets.", today, that would be "Computers do not go out on the streets." Although protest events spread on Facebook, Twitter or Youtube, they do not start or end there. The heart of the social activity beats on the streets, not on the screen. Therefore, it is important to understand the impact of new communication technologies on the dynamics of participation in civic and social movements in the upcoming period, which will be largely driven by and shaped by communication technologies.

\section{Reference}

Allbrecht, S. (2006). Whose voice is heard in online deliberation? A study of participation and representation in political debates on the Internet. Information. Communication and Society, 9 (1), 62-82. doi: 10.1080/13691180500519548.

Atkeson, L. R. \& Rapoport, R. B. (2003). The More Things Change the More They Remain the Same: Examining Gender Differences in Political Opinionation: 1952-2000. Public Opinion Quarterly, 67, 495-521.

Bakker, T. P. \& de Vreese, C. H. (2011). Good News for the Future? Young People, Internet Use, and Political Participation. Communication Research, 38(4), 451-470. doi: 10.1177/0093650210381738.

Barney, D. (2010). Excuse us if we don't give a fuck: The (anti-)political career of participation. Jeunesse: Young People, Texts and Culture, 2 (2), 138-146. http://darinbarneyresearch.mcgill.ca/Work/Excuse\%20us.pdf. 
Baumgartner, J., \& Morris, J. (2010). Myfacetube Politics: Social Networking Web Sites and Political Engagement of Young Adults. Social Science Computer Review, 28, 24-44. doi: $10.1177 / 0894439309334325$.

Bimber, B. (1999). The Internet and Citizen Communication with Government: Does the Medium Matter? Political Communication, 16 (4), 409-428. doi: 10.1080/105846099198569.

Bohl, B. (2015). Social Media Usage Among University Students in China, Occam's Razor, 5 (1), 1-12.

Boulianne, S. (2009). Does Internet use affect engagement? A meta-analysis of research. Political Communication, 26 (2), 193-211. doi: 10.1080/10584600902854363.

Boulianne, S. (2015). Social media use and participation: a metaanalysis of current research. Information, Communication \& Society, 18 (5), 524-538. doi: 10.1080/1369118X.2015.1008542.

Boyd, D. \& Ellison, N. (2008). Social Network Sites: Definition, History, and Scholarship, Journal of Computer-Mediated Communication, 13(1), 210-230. doi:10.1111/j.10836101.2007.00393.x.

Brady, H., Verba, S. \& Schlozman, K. L. (1995). Beyond SES: A Resource Model of Political Participation. The American Political Science Review, 89 (2), 271-294. doi: $10.2307 / 2082425$.

Burns, N., Schlozman, K. L. \& Verba, S. (2001). The Private Roots of Public Action: Gender, Equality and Political Participation. Cambridge, MA: Harvard Universityll\&ress.

Calenda, D., \& Meijer, A. (2009). Young People, the Internet and Political Participation. Findings of a Web Survey in Italy, Spain and The Netherlands. Information, Communication \& Society, 12 (6), 879-898. doi: 10.1080/13691180802158508.

Cammaerts, B., \& Van Audenhove, L. (2005). Online Political Debate, Unbounded Citizenship, and the Problematic Nature of a Transnational Public Sphere. Political Communication, 22 (2), 179-196. doi: 10.1080/10584600590933188.

Campbell, D. E. (2009). Civic Engagement and Education: An Empirical Test of the Sorting Model. American Journal of Political Science, 53 (4), 771-786. doi: 10.1111/j.15405907.2009.00400.x.

Cantijoch, M. (2012). Digital Media and Offline Political Participation in Spain. In E. Anduiza, M. J. Jensen, L. Jorba (Eds.), Digital Media and Political Engagement Worldwide: A Comparative Study (pp. 118-137). Cambridge: Cambridge University Press.

Carlisle, J. E. \& Patton, R. C. (2013). Is Social Media Changing how we Understand Political Engagement? An Analysis of Facebook and the 2008 Presidential Election. Political Research Quarterly, 66, 883-895. doi: 10.1177/1065912913482758.

Chiu, P.Y., Cheung, C., \& Lee, M. (2008). Online Social Networks: Why Do "We" Use Facebook? Berlin: Springer-Verlag.

Christensen, H. (2011). Political activities on the Internet: Slacktivism or political participation by other means?. First Monday, 16 (2), 7. Retrieved December 01, 2017 from http://firstmonday.org/htbin/cgiwrap/bin/ojs/index.php/fm/article/view/3336/2767

Coffé, H. \& Bolzendahl, C. (2010). Same Game, Different Rules? Gender Differences in Political Participation. Sex Roles, 62 (5), 318-333. doi: 10.1007/s11199-009-9729-y.

Dahlgren, P. (2009). Media and Political Engagement. Cambridge: Cambridge University Press.

Dalton, R. \& Wattenberg, M. (2000). Parties without Partisans: Political Change in Advanced Industrial Democracies. Oxford: Oxford University Press. 
de Vreese, C. H. (2005). The Spiral of Cynicism Reconsidered: The Mobilizing Function of News. European Journal of Communication, 20 (3), 283-301. doi: $10.1177 / 0267323105055259$.

Della Porta, D., \& Mosca, L. (2005). Global-net for global movements? A network of networks for a movement of movements. Journal of Public Policy, 25(1), 165-190.

Delli Carpini, M.X. \& Keeter, S. (1996). What Americans Know About Politics and Why it Matters. New Haven, CT: Yale University Press.

Demir, S. E. (2016). İnternetin Politik Katılıma Etkisi. Ankara Üniversitesi Sosyal Bilimler Dergisi, 7 (2), 161-191. doi: 10.1501/sbeder_0000000129.

di Gennaro, C., \& Dutton, W. (2006). The Internet and the Public: Online and Offline Political Participation in the United Kingdom. Parliamentary Affairs, 59 (2), 299-313. doi: $10.1093 / \mathrm{pa} / \mathrm{gs} 1004$.

di Maggio, P., Hargittai, E., Neuman, R., \& Robinson, J. (2001). Social implications of the Internet. Annual Review of Sociology, 27, 307-336. doi: 10.1146/annurev.soc.27.1.307.

Dordevic, J. \& Zezelj, I. (2016). Civic Activism Online: Making Young People Dormant or More Active in Real Life? Computers in Human Behavior, 70, 113-118. doi: 10.1016/j.chb.2016.12.070.

Duran, H. (2005). Siyasal Katılmayı Etkileyen Faktörler Üzerine Bir Araştırma: Tavşanlı Kütahya Örneği, Dumlupınar Üniversitesi Sosyal Bilimler Dergisi, 13, 131-152.

Enjolras, B., Steen-Johnsen, K., \& Wollebæk, D. (2013). Social media and mobilization to offline demonstrations: Transcending participatory divides? New Media1 19 Society, 15, 890-908. doi: 10.1177/1461444812462844.

Enns, S., Malinick, T. \& Matthews, R. (2008). It's not Only Who You Know, It's Also Where They Are: Using the Position Generator to Investigate the Structure of Access to Embedded Resources. In N. Lin \& B. H. Erickson (Eds.), Social Capital: An International Research Program (pp. 255-307). New York, NY: Oxford University Press.

Eymen, E. (2007). SPSS 15.0 Veri Analizi. İstatistik Merkezi, İstanbul.

Fenton, N., \& Barassi, V. (2011). Alternative media and social networking sites: The politics of nindividuation and political participation. The Communication Review, 14, 179-196. doi.org/10.1080/10714421.2011.597245.

Gallego, A. (2008). Political Participation in Europe. International Journal of Sociology, 37 (4), 10-25. doi: 10.2753/IJS0020-7659370401.

Gibson, R., \& Cantijoch, M. (2013). Conceptualizing and Measuring Participation in the Age of the Internet: Is Online Political Engagement Really Different to Offline? The Journal of Politics, 75 (3), 701-716. doi:10.1017/S0022381613000431.

Gil de Zúñiga, H., Jung, N. \& Valenzuela, S. (2012). Social Media Use for News and Individuals, Social Capital, Civic Engagement and Political Participation. Journal of Computer Mediated Communication, 17 (3), 319-344. doi: 10.1111/j.10836101.2012.01574.x.

Gil de Zúñiga, H., Molyneux, L. \& Zheng, P. (2014). Social Media, Political Expression, and Political Participation: Panel Analysis of Lagged and Concurrent Relationships, Journal of Communication, 64, 612-634. doi:10.1111/jcom.12103.

Gladwell, M. (2010, October 4). Small Change: Why the Revolution will not be Tweeted. The New Yorker, Retrieved November 13, 2017, from http://www.newyorker.com/reporting/2010/10/04/101004fa_fact_gladwell?currentPage $=$ all\#ixzz10raPq1SX.

Glynn, C. J., Huge, M. E. \& Hoffman, L. H. (2012). All the News That's Fit to Post: A Profile of News Use on Social Networking Sites. Computers in Human Behavior, 28 (1), 113119. doi: 10.1016/j.chb.2011.08.017. 
Graeff, E. (2016) 'Youth Digital Activism.' In Youth Civic Engagement: United Nations World Youth Report. New York, NY: United Nations, pp. 95-107. https://damprod.media.mit.edu/x/2016/10/20/Graeffun_world_youth_report_youth_civic_engagement-excerpt.pdf.

Halupka, M. (2014). Clicktivism: A Systematic Heuristic. Policy and Internet, 6 (2), 115-132. Hamid, A. N., Ishak, M. S., Ismail, S. A. \& Yazam, N. M. (2013). Social Media Usage Among University Students in Malaysia. Global Journal of Business and Social Science Review. 1 (1), 124-132. doi: 10.4018/978-1-4666-2851-9.ch012.

Hirzalla, F. \& Van Zoonen, L. (2010). Beyond the Online/Offline Divide: How Youth's Online and Offline Civic Activities Converge. Social Science Computer Review, 29 (4), 481-498. doi:10. 1177/0894439310385538.

Jackson, L.A., Ervin, K.S., Gardner, P.D. \& Schmitt, N. (2001). Gender and the Internet: Women Communicating and Men Searching. Sex Roles, 44 (5), 363-379. doi: 10.1023/A:1010937901821.

Johnston, K., Chen, M. \& Hauman, M. (2013). Use, Perception and Attitude of University Students Towards Facebook and Twitter. The Electronic Journal Information Systems Evaluation, 16 (3), 201-211.

Joyce, M. (2010). Introduction: How to Think About Digital Activism. In M. Joyce (Eds.), Digital Activism Decoded: The New Mechanics of Change (pp. 1-14). International Debate Education Association, New York: IDEBATE Press.

Junco, R., Heiberger, G. \& Loken, E. (2011). The Effect of Twitter on Callege Student Engagement and Grades. Journal of Computer Assisted Learning, 27 (2), 119-132. doi: 10.1111/j.1365-2729.2010.00387.x.

Junco, R., Merson, D. \& Salter, D. (2010). The Effect of Gender, Ethnicity, and Income on College Students' Use of Communication Technologies. Cyberpsychology, Behavior, and Social Networking, 13(6), 619-627. doi: 10.1089/cyber.2009.0357.

Jung, N., Kim, Y. \& Gil de Zúniga, H. (2011). The Mediating Role of Knowledge and Efficacy in the Effects of Communication on Political Participation. Mass Communication and Society, 14 (4), 407-430. doi: 10.1080/15205436.2010.496135.

Kahn, R., \& Keller, D. (2004). New Media and Internet Activism: From the 'Battle of Seattle' to Blogging. New Media and Society, 6 (1), 87-95.

Kahne, J. \& Middaugh, E. (2012). Digital Media Shapes Youth Participation in Politics. Phi Delta Kappan, 94 (3), 52-56.

Kahne, J., Lee, N.J., Feezell, J.T. (2013). The Civic and Political Significance of Online Participatory Cultures among Youth Transitioning to Adulthood. Journal of Information Technology and Politics, 10 (1), 1-20. doi: 1080/19331681.2012.701109.

Kalaycığlu, E. (1983). Karşılaştırmalı Siyasal Katılma Siyasal Eylemin Kökenleri Üzerine Bir İnceleme. İstanbul: İstanbul Üniversitesi Siyasal Bilimler Fakültesi Yayınları No:10.

Karagöz, K. (2013). Yeni Medya Çağında Dönüşen Toplumsal Hareketler ve Dijital Aktivizm Hareketleri. Illetişim ve Diplomasi, 1 (1), 24-47.

Keating, A. \& Melis, G. (2017). Social Media and Youth Political Engagement: Preaching to the Converted or Providing a New Voice for Youth? The British Journal of Politics and International Relations, 19 (4), 877-894. doi: 10.1177/1369148117718461.

Kellner, D. (1999). Globalization From Below? Toward a Radical Democratic Technopolitics. Angelaki, 4 (2), 101-113.

Koçer, M. (2012). Erciyes Üniversitesi Öğrencilerinin İnternet ve Sosyal Medya Kullanım Alışkanlıkları, Akdeniz İletişim, 18, 70-85.

Kushin, M. \& Yamamoto, M. (2010). Did Social Media Really Matter? College Students' Use of Online Media and Political Decision Making in the 2008 Election. Mass Communication \& Society, 13, 608-630. doi: 10.1080/15205436.2010.516863 
Lazarsfeld P. F., \& Merton R. K. (1948) Mass Communication, Popular Taste and Organized Social Action. New York: Bobbs-Merill.

Lee, C. S. \& Ma, L. (2012). News Sharing in Social Media: The Effect of Gratifications and Prior Experience. Computers in Human Behavior, 28 (2), 331-339. doi: 10.1016/j.chb.2011.10.002.

Lee, Y.H., \& Hsieh, G. (2013, April). Does Slacktivism Hurt Activism? The effect of moral balancing and consistency in online activism. Paper presented at the SIGCHI Conference on human factors in computing systems, Paris, France.

Lutz, C., Hoffmann C. P. \& Meckel, M. (2014). Beyond Just Politics: a systematic literature review on online participation. First Monday, 19 (7). Retrieved November 20, 2018 from https://firstmonday.org/ojs/index.php/fm/article/view/5260/4094.

Metzger, M., Erete, S., Barton, D. \& Lewis, D. (2015). The New Political Voice of Young Americans: Online Engagement and Civic Development among Firstyear College Students. Education, Citizenship and Social Justice, 10 (1), 55-66. doi: 10.1177/1746197914558398.

Mihailidis, P. (2014). The Civic-Social Media Disconnect: Exploring Perceptions of Social Media for Engagement in the Daily Life of College Students. Information, Communication \& Society, 17, 1059-1071. doi: 10.1080/1369118X.2013.877054.

Morozov, E. (2009, May 19). The Brave New World of Slacktivism. Foreign Policy, Retrieved November 17, 2017, from https://www.npr.org/templates/story/story.php?storyId=104302141. 121

Morozov, E. (2011). The Net Delusion: The Dark Side of Internet Freedom. New York: PublicAffairs.

Mossberger, K., Tolbert, C., \& McNeal, R. (2008). Digital Citizenship: The Internet, Society and Participation. Cambridge: MIT Press.

Norris, P. (2002). Democratic Phoenix: Political Activism Worldwide. New York: Cambridge University Press.

Okur, H. D. \& Özkul, M. (2015). Modern İletişimin Arayüzü: Sanal İletişim Sosyal Paylaşım Sitelerinin Toplumsal İlişki Kurma Biçimlerine Etkisi (Facebook Örneği). Süleyman Demirel Üniversitesi Sosyal Bilimler Enstitüsü Dergisi, 21, 213-246.

Ono, H. \& Zavodny, M. (2003). Gender and the Internet. Social Science Quarterly, 84 (1), 111-121. doi: 10.1111/1540-6237.t01-1-8401007.

Oser, J., Hooghe, M. \& Marien, S. (2013). Is Online Participation Distinct from Offline Participation? A Latent Class Analysis of Participation Types and Their Stratification. Political Research Quarterly, 66 (1), 91-101. doi: 10.1177/1065912912436695

Özdemir, Ö. (2015). Başarısız bir sosyal medya deneyimi: Occupy Wall Street. Retrieved December 22, 2017 from http://www.sendika.org/2015/01/basarisiz-bir-sosyal-medyadeneyimi-occupy-wall-street-onder-ozdemir.

Papacharissi, Z. (2009). The virtual sphere 2.0: The Internet, the public sphere, and beyond. In A. Chadwick (Eds.), Routledge Handbook of Internet Politics (pp. 230-245). Abingdon: Routledge.

Pilli, O. (2015). The Changes in Social Media Usage: Students' Perspective. The Anthropologist, 22 (2), 345-354. doi: 10.1080/09720073.2015.11891886.

Pritzker, S., Springer, M., McBride, A. M. (2012) Learning to Vote: Informing Political Participation Among College Students. Journal of Community Engagement and Scholarship, 8 (1), 69-79.

Putnam, R. (2000). Bowling Alone: The Collapse and Revival of American Community. New York: Simon \& Schuster. 
Quintelier, E. \& Vissers, S. (2008). The Effect of Internet Use on Political participation: An Analysis of Survey Results for 16-Year-Olds in Belgium. Social Science Computer Review, Winter, 26 (4), 411-427. doi: 10.1177/0894439307312631.

Rheingold, H. (1993). The Virtual Community: Homesteading on the Electronic Frontier. Cambridge: The MIT Press.

Rideout, V., Foehr, U. \& Roberts, D. (2010). Generation $\mathrm{m}^{2}$ : Media in the Lives of 8-to 18year-olds. Menlo Park, CA: Kaiser Family Foundation.

Roberts, D. F., \& Foehr, U. G. (2008). Trends in Media Use. The Future of Children, 18, 1137.

Rosenstone, S. J., Hansen, J. (1993) Mobilization, Participation, and Democracy in America, New York: Macmillan.

Rotman, D., Vieweg, S., Yardi, S., Chi, E., Preece, J., Shneiderman, B., \& Pirolli, P. (2011, January). From Slacktivism to Activism: Participatory Culture in the Age of Social Media. Proceedings of the CHI Extended Abstracts on Human Factors in Computing Systems (pp. 819-822). New York., NY.

Schlozman, K. L., Burns, N. \& Verba, S. (1999). What Happened at Work Today?: A Multistage Model of Gender, Employment, and Political Participation. Journal of Politics, 61, 29-53. doi: 10.2307/2647774.

Schlozman, K., Verba, S. \& Brady, H. (2012). The Unheavenly Chorus: Unequal Political Voice and the Broken Promise of American Democracy. Princeton, NJ: Princeton University Press.

Scholz, T. (2010). Infrastructure: Its Transformations and Effect on Digital Activism. In M. Joyce (Eds.), Digital Activism Decoded: The New Mechanics of Change (pp. 17-32). International Debate Education Association, New York: IDEBATE Press.

Shirky, C. (2011). The Political Power of Social Media. Foreign Affairs, 90 (1), 28-41.

Skues, J. L., Williams, B. \& Wise, L. (2012). The Effects of Personality Traits, Selfesteem, Loneliness, and Narcissism on Facebook use among University Students. Computers in Human Behavior, 28 (6), 2414-2419. doi: 10.1016/j.chb.2012.07.012.

Şener, G., Emre, P. \& Akyıldız, F. (2015). Türkiye'de Sosyal Medyanın Siyasi Katılıma Etkisi. Folklor/Edebiyat, 21 (3), 75-98.

Tatar, T. (2003). Malatya'da Siyasi Katılım: Karşılaştırmalı Bir Analiz, Fırat Üniversitesi Sosyal Bilimler Dergisi, 13 (1), 331-350.

Tektaş, N. (2014). Üniversite Öğrencilerinin Sosyal Ağları Kullanımlarına Yönelik Bir Araştırma. Tarih Okulu Dergisi (TOD), 17 (15), 851-870.

Theocharis, Y. \& Lowe, W. (2016). Does Facebook Increase Political Participation? Evidence from a Field Experiment. Information, Communication \& Society, 19 (10), 1465-1486. doi: 10.1080/1369118X.2015.1119871.

Theocharis, Y. \& Quintelier, E. (2014). Stimulating citizenship or expanding entertainment? The effect of Facebook on adolescent participation. New Media \& Society, 18 (1), 817 836.doi: $10.1177 / 1461444814549006$

Twenge, J. M. (2009). Ben Nesli. (Çev. E. Öztürk). İstanbul: Kaknüs Yayınları.

Valenzuela, S., Park, N. \& Kee, K. F. (2009) Is there social capital in a social network site?: Facebook use and college students' life satisfaction, trust, and participation. Journal of Computer-Mediated Communication, 14 (4), 875-901. doi: 10.1111/j.10836101.2009.01474.x.

Verba, S., Burns, N. \& Schlozman, K. L. (.1997) Knowing and caring about politics: Gender and political engagement. Journal of Politics, 59, 1051-1072.

Verba, S., Schlozman, K. L. \& Brady, H. E. (1995). Voice and Equality: Civic Voluntarism in American Politics. Harvard, MA: Harvard University Press. 
Visser, S., \& Stolle, D. (2014). The Internet and New Modes of Political Participation: Online versus Offline Participation. Information, Communication \& Society, 17 (8), 937-955. doi: 10.1080/1369118X.2013.867356.

Vitak, J., Zube, P., Smock, A., Ellison, N. \& Lampe, C.(2009). Poking People to Participate: Facebook and Political Participation in the 2008 Election. Paper presented at the Annual Conference of the International Communication Association, Chicago.

Ward, J. (2016) Riding the wave: How the ALS Ice Bucket Challenge used storytelling and user-generated content to embrace slacktivism, in Public Relations and Participatory Culture: Fandom, social media and community engagement, Amber Hutchins \& N. T. Tindall (Eds.), New York: Routledge, 169-180.

Wasserman, I. \& Richmond-Abbott, M. (2005). Gender and the Internet: Causes of Variations in Access, Level, and Scope of Use. Social Science Quarterly, 86 (1), 252-270.

Wellman, B., Hasse, A.Q., \& Witte, J., Hampton, K. (2001). Does the Internet increase, decrease, or supplement social capital? American Behavioral Scientist, 45, 436-55. doi: $10.1177 / 00027640121957286$

Wen, N., Xiaoming, H. \& George, C. (2013). Gender and Political Participation: News Consumption, Political Efficacy and Interpersonal Communication. Asian Journal of Women's Studies, 19 (4), 124-149, doi: 10.1080/12259276.2013.11666168.

Willis, S., \& Tranter, B. (2006). Beyond the 'digital divide' - Internet diffusion and inequality in Australia. Journal of Sociology, 42 (1), 43-59. doi: 10.1177/1440783306061352.

Xenos, M. \& Moy, P. (2007). Direct and differential effects of the internet dropolitical and civic engagement. Journal of Communication, 57 (4), 704-718. doi: 10.1111/j.14602466.2007.00364.x.

Xenos, M., Vromen, A. \& Loader, B. D. (2014). The great equalizer? Patterns of Social Media Use and Youth Political Engagement in Three Advanced Democracies. Information, Communication \& Society, 17 (2), 151-167. doi: 10.1080/1369118X.2013.871318.

Yamamoto, M., Kushin, M.J., Dalisay, F. (2013) Social Media and Mobiles as Political Mobilization Forces for young Adults: Examining the Moderating Role of Online Political Expression in Political Participation. New Media \& Society, 17 (2), 880-898. doi: $10.1177 / 1461444813518390$.

Yang, H. C. \& DeHart, J. L. (2016). Social Media Use and Online Political Participation among College Students during the US Election 2012. Social Media + Society, January-March, 1-18.

Zhang, T., Johnson, T., Seltzer, T. \& Bichard, S. L. (2009). The Revolution Will be Networked: The Influence of Social Networking Sites on Political Attitudes and Behavior. Social Science Computer Review, 28 (1), 75-92. doi: 10.1177/0894439309335162.

Zhao, S., Grasmuck, S., \& Martin, J. (2008). Identity Construction on Facebook: Digital Empowerment in Anchored Relationship. Journal of Computers in Human Behavior, 24, 5-13. doi: 10.1016/j.chb.2008.02.012.

Zukin, C,. Keeter, S. \& Andolina, M. (2006). A New Engagement? Political Participation, Civic Life, and the Changing American Citizen. Oxford: Oxford University Press. 